ARTICLE

\title{
One-step ethylene production from a four- component gas mixture by a single physisorbent
}

Jian-Wei Cao (1) 1,6, Soumya Mukherjee (10) 2,3,6, Tony Pham (1) 4, Yu Wang1, Teng Wang1, Tao Zhang (1) 1, Xue Jiang ${ }^{1}$, Hui-Juan Tang${ }^{1}$, Katherine A. Forrest ${ }^{4}$, Brian Space ${ }^{4,5}$, Michael J. Zaworotko ${ }^{2 凶}$ \& Kai-Jie Chen (iD ${ }^{1 \times}$

One-step adsorptive purification of ethylene $\left(\mathrm{C}_{2} \mathrm{H}_{4}\right)$ from four-component gas mixtures comprising acetylene $\left(\mathrm{C}_{2} \mathrm{H}_{2}\right)$, ethylene $\left(\mathrm{C}_{2} \mathrm{H}_{4}\right)$, ethane $\left(\mathrm{C}_{2} \mathrm{H}_{6}\right)$ and carbon dioxide $\left(\mathrm{CO}_{2}\right)$ is an unmet challenge in the area of commodity purification. Herein, we report that the ultramicroporous sorbent $\mathrm{Zn}$-atz-oba $\left(\mathrm{H}_{2} \mathrm{Oba}=4,4\right.$-dicarboxyl diphenyl ether; Hatz $=3$-amino1,2,4-triazole) enables selective adsorption of $\mathrm{C}_{2} \mathrm{H}_{2}, \mathrm{C}_{2} \mathrm{H}_{6}$ and $\mathrm{CO}_{2}$ over $\mathrm{C}_{2} \mathrm{H}_{4}$ thanks to the binding sites that lie in its undulating pores. Molecular simulations provide insight into the binding sites in $\mathrm{Zn}$-atz-oba that are responsible for coadsorption of $\mathrm{C}_{2} \mathrm{H}_{2}, \mathrm{C}_{2} \mathrm{H}_{6}$ and $\mathrm{CO}_{2}$ over $\mathrm{C}_{2} \mathrm{H}_{4}$. Dynamic breakthrough experiments demonstrate that the selective binding exhibited by $\mathrm{Zn}$-atz-oba can produce polymer-grade purity (>99.95\%) $\mathrm{C}_{2} \mathrm{H}_{4}$ from binary $\left(1: 1\right.$ for $\mathrm{C}_{2} \mathrm{H}_{4} /$ $\mathrm{C}_{2} \mathrm{H}_{6}$ ), ternary (1:1:1 for $\mathrm{C}_{2} \mathrm{H}_{2} / \mathrm{C}_{2} \mathrm{H}_{4} / \mathrm{C}_{2} \mathrm{H}_{6}$ ) and quaternary (1:1:1:1 for $\mathrm{C}_{2} \mathrm{H}_{2} / \mathrm{C}_{2} \mathrm{H}_{4} / \mathrm{C}_{2} \mathrm{H}_{6} /$ $\mathrm{CO}_{2}$ ) gas mixtures in a single step.

\footnotetext{
${ }^{1}$ Key Laboratory of Special Functional and Smart Polymer Materials of Ministry of Industry and Information Technology, Xi'an Key Laboratory of Functional Organic Porous Materials, School of Chemistry and Chemical Engineering, Northwestern Polytechnical University, Xi'an, Shaanxi, PR China. ${ }^{2}$ Bernal Institute, Department of Chemical Sciences, University of Limerick, Limerick, Republic of Ireland. ${ }^{3}$ Department of Chemistry, Technical University of Munich, Garching b, München, Germany. ${ }^{4}$ Department of Chemistry, University of South Florida, Tampa, FL, USA. ${ }^{5}$ Department of Chemistry, North Carolina State University, Raleigh, USA. ${ }^{6}$ These authors contributed equally: Jian-Wei Cao, Soumya Mukherjee. ${ }^{凶}$ email: xtal@ul.ie; ckjiscon@nwpu.edu.cn
} 
thylene $\left(\mathrm{C}_{2} \mathrm{H}_{4}\right)$ is a feedstock for the production of plastics, detergents and coatings and its production, now approaching 200 million tons per year, continues to grow ${ }^{1}$. The energy footprints for purification of $\mathrm{C}_{2} \mathrm{H}_{4}$ and propylene $\left(\mathrm{C}_{3} \mathrm{H}_{6}\right)$, also one of the highest volume products of the chemical industry, account for $c a .0 .3 \%$ of the global energy demand ${ }^{2}$. The presence of impurities is a consequence of the steam pyrolysis process used to produce $\mathrm{C}_{2} \mathrm{H}_{4}$, which in turn results in acetylene $\left(\mathrm{C}_{2} \mathrm{H}_{2}\right)$, carbon dioxide $\left(\mathrm{CO}_{2}\right)$, ethane $\left(\mathrm{C}_{2} \mathrm{H}_{6}\right)$ and other downstream products including propylene $\left(\mathrm{C}_{3} \mathrm{H}_{6}\right)$, propane $\left(\mathrm{C}_{3} \mathrm{H}_{8}\right)$, hydrogen $\left(\mathrm{H}_{2}\right), \mathrm{C} 4$ and higher light hydrocarbons ${ }^{3,4}$, which are easily separated by the difference of boiling points. Polymer-grade ( $>99.95 \%$ purity) $\mathrm{C}_{2} \mathrm{H}_{4}$ is generated by stepwise removal in downstream purification processes: $\mathrm{CO}_{2}$ is removed using caustic soda; $\mathrm{C}_{2} \mathrm{H}_{2}$ is eliminated via catalytic hydrogenation with noblemetal catalysts at high temperature and pressure; cryogenic distillation is typically employed to remove $\mathrm{C}_{2} \mathrm{H}_{6}{ }^{5}$.

To mitigate the high energy footprint of $\mathrm{C}_{2} \mathrm{H}_{4}$ production, researchers have typically focused upon the development of a new generation of physisorbents that exhibit affinity for one gas over others in a gas mixture. The promise of physisorbents lies with their relatively low energy consumption compared to distillation processes thanks to facile regeneration/recycling 6 . However, physisorbents tend to be unsuitable for ethylene purification because the kinetic diameter of $\mathrm{C}_{2} \mathrm{H}_{4}(4.1 \AA)$ sits between $\mathrm{CO}_{2}$ (3.3 $\AA), \mathrm{C}_{2} \mathrm{H}_{2}(3.3 \AA)$ and $\mathrm{C}_{2} \mathrm{H}_{6}(4.4 \AA)$, precluding the possibility of molecular sieving by pore size engineered physisorbents ${ }^{7}$. Since the quadrupole moment of $\mathrm{C}_{2} \mathrm{H}_{4}\left(1.5 \times 10^{-26} \mathrm{esu} \mathrm{cm}^{2}\right)$ also lies between $\mathrm{CO}_{2}\left(4.3 \times 10^{-26} \mathrm{~cm}^{2}\right), \mathrm{C}_{2} \mathrm{H}_{2}\left(7.2 \times 10^{-26} \mathrm{esu} \mathrm{\textrm {cm } ^ { 2 }}\right)$ and $\mathrm{C}_{2} \mathrm{H}_{6}\left(0.65 \times 10^{-26} \text { esu cm}\right)^{2}$, one-step purification of $\mathrm{C}_{2} \mathrm{H}_{4}$ by thermodynamics (selective binding) has thus far proven to be elusive. Metal organic materials $(\mathrm{MOMs})^{9}$, also called metalorganic frameworks (MOFs) ${ }^{10,11}$ or porous coordination polymers (PCPs) ${ }^{12}$, have promising applications as $\mathrm{C} 2$ and $\mathrm{CO}_{2}$ selective physisorbents for several binary mixtures, including $\mathrm{C}_{2} \mathrm{H}_{2} / \mathrm{C}_{2} \mathrm{H}_{4}, \mathrm{C}_{2} \mathrm{H}_{4} / \mathrm{C}_{2} \mathrm{H}_{6}, \mathrm{C}_{2} \mathrm{H}_{6} / \mathrm{C}_{2} \mathrm{H}_{4}, \mathrm{C}_{2} \mathrm{H}_{2} / \mathrm{CO}_{2}$ and $\mathrm{CO}_{2} /$ $\mathrm{C}_{2} \mathrm{H}_{2}{ }^{13-34}$ There are also examples of physisorbents that are effective against ternary $\mathrm{C} 2$ and $\mathrm{C} 2-\mathrm{CO}_{2}$ mixtures such as $\mathrm{C}_{2} \mathrm{H}_{2}$ / $\mathrm{C}_{2} \mathrm{H}_{4} / \mathrm{C}_{2} \mathrm{H}_{6}$ and $\mathrm{C}_{2} \mathrm{H}_{2} / \mathrm{C}_{2} \mathrm{H}_{4} / \mathrm{CO}_{2}{ }^{35-41}$. Certain classes of physisorbents are amenable to systematic fine-tuning of pore chemistry and pore size 42,43 and have resulted in "second generation" sorbents with $>$ one order of magnitude improvement in performance $18,24,44,45,47$. Nevertheless, we are aware of only one report of $\mathrm{C}_{2} \mathrm{H}_{4}$ purification from quaternary mixtures using physisorbents as reported by us in 2019 by introducing the synergistic sorbent separation technology (SSST) ${ }^{46}$ concept, which enables one-step production of high-purity ethylene from a quaternary $\mathrm{C}_{2} \mathrm{H}_{2}-\mathrm{C}_{2} \mathrm{H}_{4}-\mathrm{C}_{2} \mathrm{H}_{6}-\mathrm{CO}_{2}$ mixture by exploiting three benchmark sorbents, Zn-atz-ipa, SIFSIX-3-Ni, and TIFSIX-2-Cui. These sorbents were tandem-packed in a single column to sequentially remove $\mathrm{C}_{2} \mathrm{H}_{6}, \mathrm{CO}_{2}$, and $\mathrm{C}_{2} \mathrm{H}_{2}$, respectively (Fig. 1). Unfortunately, the interplay of packing sequence and gas mass transfer in SSST can make industrial-scale processes infeasible and, as illustrated in Fig. 1, a single sorbent that coadsorbs $\mathrm{C}_{2} \mathrm{H}_{2}$, $\mathrm{C}_{2} \mathrm{H}_{6}$, and $\mathrm{CO}_{2}$ would be desirable for quaternary gas separations such as the purification of $\mathrm{C}_{2} \mathrm{H}_{4}$ from a $\mathrm{C}_{2} \mathrm{H}_{2}-\mathrm{C}_{2} \mathrm{H}_{4}-\mathrm{C}_{2} \mathrm{H}_{6}-\mathrm{CO}_{2}$ mixture. Herein we report that the challenge of one-step $\mathrm{C}_{2} \mathrm{H}_{4}$ purification from a quaternary mixture $\left(\mathrm{C}_{2} \mathrm{H}_{2}-\mathrm{C}_{2} \mathrm{H}_{4}-\mathrm{C}_{2} \mathrm{H}_{6}-\mathrm{CO}_{2}\right)$ is achieved by a single physisorbent, the ultramicroporous coordination network Zn-atz-oba.

\section{Results}

Synthesis and characterization of Zn-atz-oba. Zn-atz-oba was synthesized following a previously reported protocol (for details see Methods section $)^{47}$. The bulk phase purity of crystalline samples was confirmed by powder X-ray diffraction, PXRD (Fig. 2c). As shown in Fig. 2a, b, Zn(II) cations are linked by atz ${ }^{-}$ anions to form 2D undulating layers with dinuclear $\mathrm{Zn}$ (II) clusters as nodes. These layers are further cross-linked via oba ${ }^{2-}$ ligands to form a pcu topology network. As revealed by thermogravimetric analysis (Supplementary Fig. 1), activated Zn-atzoba is fully desolvated and stable until ca. $673 \mathrm{~K}$. As calculated by PLATON $^{48}$, the void space of $\mathrm{Zn}$-atz-oba is $35.9 \%$.

The pore volume, Langmuir and Brunauer-Emmett-Teller (BET) specific surface area for $\mathrm{Zn}$-atz-oba are $0.287 \mathrm{~cm}^{3} \mathrm{~g}^{-1}$, $783.1 \mathrm{~m}^{2} \mathrm{~g}^{-1}$, and $710.7 \mathrm{~m}^{2} \mathrm{~g}^{-1}$, respectively, as calculated from its cryogenic $(77 \mathrm{~K}) \mathrm{N}_{2}$ adsorption isotherm (Supplementary Figs. 2-4). Both parameters are in agreement with the crystal structure derived pore volume $\left(0.283 \mathrm{~cm}^{3} \mathrm{~g}^{-1}\right)$ and the Langmuir surface area calculated therefrom $\left(755 \mathrm{~m}^{2} \mathrm{~g}^{-1}\right)$, respectively. Horvath-Kawazoe model (pore geometry: slit) based pore size distribution analysis revealed the aperture distribution to be ultramicroporous between 0.32 and $0.44 \mathrm{~nm}$ (Supplementary Fig. 5).

Adsorption isotherm, selectivity, and enthalpy. The $\mathrm{C}_{2} \mathrm{H}_{2}$, $\mathrm{C}_{2} \mathrm{H}_{4}, \mathrm{C}_{2} \mathrm{H}_{6}$, and $\mathrm{CO}_{2}$ adsorption isotherms of activated $\mathrm{Zn}$-atzoba were recorded at 298 and $273 \mathrm{~K}$ (Fig. 2e and Supplementary Fig. 6). Interestingly, $\mathrm{C}_{2} \mathrm{H}_{2}, \mathrm{C}_{2} \mathrm{H}_{6}$, and $\mathrm{CO}_{2}$ exhibited higher adsorption uptakes at $298 \mathrm{~K}$ across the entire pressure range tested, $0-100 \mathrm{kPa}$, especially in the low-pressure region, $0-20 \mathrm{kPa}$. These uptakes suggest selective adsorption of $\mathrm{C}_{2} \mathrm{H}_{2}, \mathrm{CO}_{2}$, and $\mathrm{C}_{2} \mathrm{H}_{6}$ over $\mathrm{C}_{2} \mathrm{H}_{4}$ by $\mathrm{Zn}$-atz-oba. Low-coverage isosteric adsorption enthalpies were determined by virial fit of the isotherm data (see Methods section, Supplementary Note 2: Adsorption enthalpy calculation, and Supplementary Figs. 7-10) and the trends (Fig. 2d) correlate well with their low-pressure (until $20 \mathrm{kPa})$ saturation uptake capacities as follows: $Q_{\mathrm{st}}\left(\mathrm{C}_{2} \mathrm{H}_{6}\right)$ $\left(30.0 \mathrm{~kJ} \mathrm{~mol}^{-1}\right)>Q_{\mathrm{st}}\left(\mathrm{CO}_{2}\right) \quad\left(29.0 \mathrm{~kJ} \mathrm{~mol}^{-1}\right)>Q_{\mathrm{st}}\left(\mathrm{C}_{2} \mathrm{H}_{2}\right) \quad(27.5 \mathrm{~kJ}$ $\left.\mathrm{mol}^{-1}\right)>Q_{\mathrm{st}}\left(\mathrm{C}_{2} \mathrm{H}_{4}\right) \quad\left(27.0 \mathrm{~kJ} \mathrm{~mol}^{-1}\right)$. We also note that the adsorption enthalpies of all four gases are below $35 \mathrm{~kJ} \mathrm{~mol}^{-1}$, an indication that $\mathrm{Zn}$-atz-oba should exhibit a relatively low energy footprint for regeneration 27,45 .

Adsorption selectivity is also a key indicator of separation performance. The adsorption selectivities of $\mathrm{Zn}$-atz-oba for $\mathrm{C}_{2} \mathrm{H}_{2} /$ $\mathrm{C}_{2} \mathrm{H}_{4}, \mathrm{C}_{2} \mathrm{H}_{6} / \mathrm{C}_{2} \mathrm{H}_{4}$, and $\mathrm{CO}_{2} / \mathrm{C}_{2} \mathrm{H}_{4}$ were calculated using Ideal Adsorbed Solution Theory ${ }^{49}$ (IAST) after fitting the singlecomponent adsorption isotherms to the Langmuir-Freundlich model (Supplementary Figs. 11-14 and Supplementary Table 1). As shown in Fig. 2f, at $298 \mathrm{~K}$ and $100 \mathrm{kPa}$, the selectivities are 1.43 $\left(\mathrm{C}_{2} \mathrm{H}_{2} / \mathrm{C}_{2} \mathrm{H}_{4}\right), 1.27\left(\mathrm{C}_{2} \mathrm{H}_{6} / \mathrm{C}_{2} \mathrm{H}_{4}\right)$, and $1.33\left(\mathrm{CO}_{2} / \mathrm{C}_{2} \mathrm{H}_{4}\right) \cdot \mathrm{C}_{2} \mathrm{H}_{6} /$ $\mathrm{C}_{2} \mathrm{H}_{4}$ and $\mathrm{C}_{2} \mathrm{H}_{2} / \mathrm{C}_{2} \mathrm{H}_{4}$ selectivities for $\mathrm{Zn}$-atz-oba are comparable to the current benchmark sorbents that enable $\mathrm{C}_{2} \mathrm{H}_{4}$ purification from $\mathrm{C}_{2} \mathrm{H}_{2} / \mathrm{C}_{2} \mathrm{H}_{4} / \mathrm{C}_{2} \mathrm{H}_{6}$ 1:1:1 ternary mixtures (1.2 and 1.8 for TJT- $100^{35}, 1.46$ and 1.09 for Azole-Th- ${ }^{36}, 1.32$ and 1.4 for NPU$1^{39}, 1.4$ and 1.07 for UPC-612 and 1.5 and 1.4 for UPC- $613^{41}$, respectively) (Supplementary Table 3). The selectivity for $\mathrm{CO}_{2} /$ $\mathrm{C}_{2} \mathrm{H}_{4}$ is also comparable to that of $\mathrm{C}_{2} \mathrm{H}_{6} / \mathrm{C}_{2} \mathrm{H}_{4}$ and $\mathrm{C}_{2} \mathrm{H}_{2} / \mathrm{C}_{2} \mathrm{H}_{4}$. Grand canonical Monte Carlo (GCMC) simulations of binary mixtures containing 1:1 $\mathrm{C}_{2} \mathrm{H}_{2} / \mathrm{C}_{2} \mathrm{H}_{4}, \mathrm{C}_{2} \mathrm{H}_{6} / \mathrm{C}_{2} \mathrm{H}_{4}$, and $\mathrm{CO}_{2} / \mathrm{C}_{2} \mathrm{H}_{4}$ in $\mathrm{Zn}$-atz-oba confirmed that these selectivities are greater than 1 at $298 \mathrm{~K}$ and $1 \mathrm{~atm}$ (Supplementary Table 5). These selectivities and relatively close adsorption enthalpies suggest that $\mathrm{Zn}$-atz-oba might coadsorb the preferred sorbates $\mathrm{C}_{2} \mathrm{H}_{2}, \mathrm{C}_{2} \mathrm{H}_{6}$, and $\mathrm{CO}_{2}$ when subjected to a mixture feed.

Mechanism of gas adsorption by GCMC simulations. GCMC simulations were conducted upon $\mathrm{Zn}$-atz-oba at 273 and $298 \mathrm{~K}$ and afforded $\mathrm{C}_{2} \mathrm{H}_{4}$ and $\mathrm{CO}_{2}$ uptakes that are in good agreement with the corresponding experimental measurements at low 

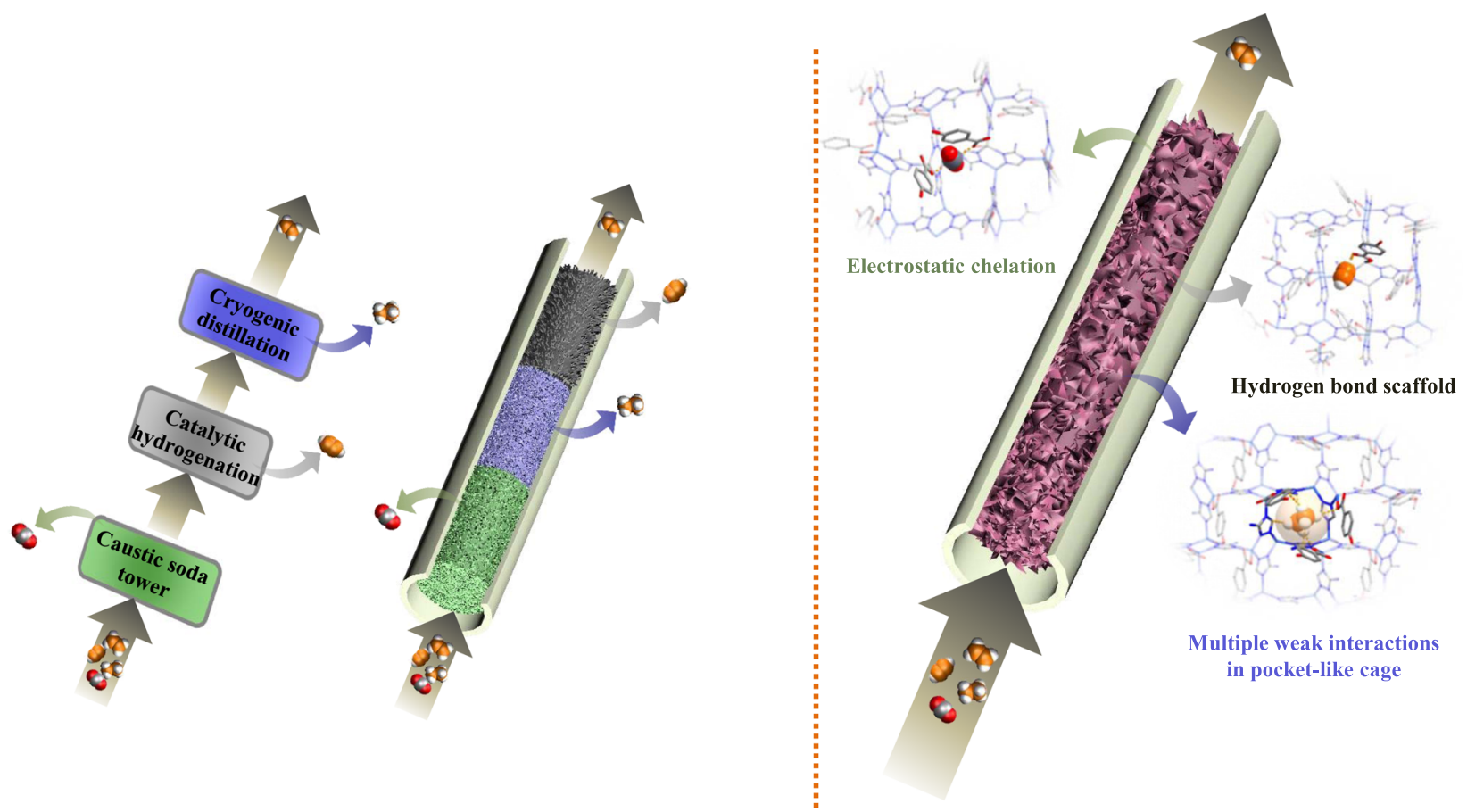

$\begin{array}{lll}\text { Present technology: } & \text { Synergistic Sorbent Separation Technology (SSST): } \\ & \text { Three-step process } & \text { One-step process } \\ >\quad \text { High pressure and temperature } & \bullet & \text { Ambient temperature and pressure } \\ > & \text { Large amounts of caustic } & \text { Lowenergy consumed for regeneration } \\ \text { soda solution } & > & \text { Complex packing processes } \\ \quad \text { Noble metal catalyst } & > & \text { Cumbersome mass transfer process }\end{array}$

One-Sorbent Separation Technology (OSST):

Single physisorbent

Simple packing process

One-step process

- Ambient temperature and pressure

- Low energy consumed for regeneration

Fig. 1 Comparison of ethylene purification technologies. State-of-the-art separation technology is compared to synergistic sorbent separation technology (SSST) and "one-sorbent separation technology", OSST.

(a)

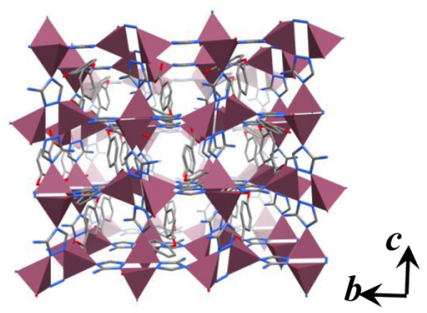

(b)

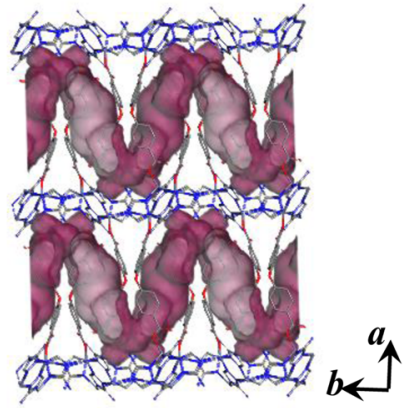

(c)

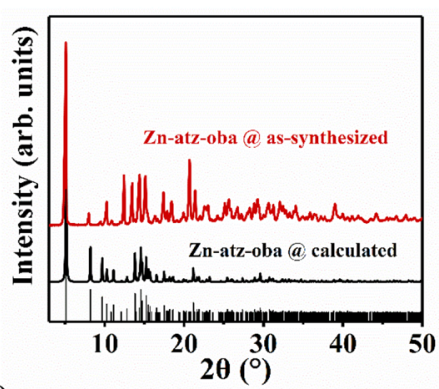

(d)

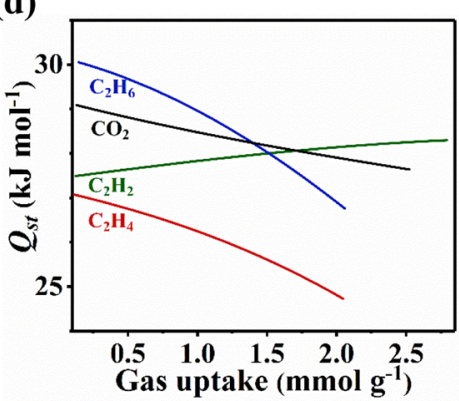

(e)

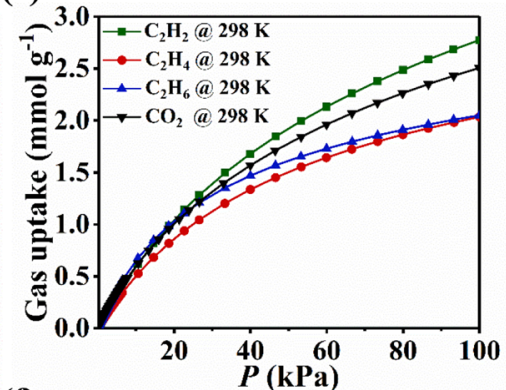

(f)

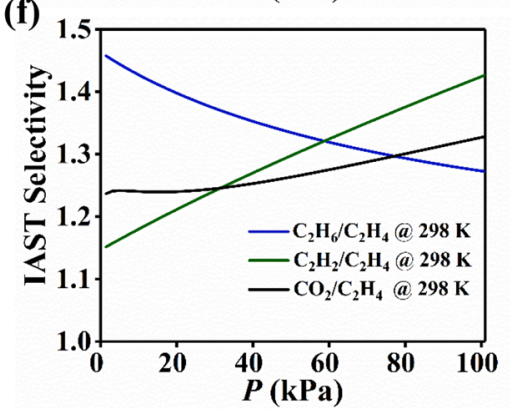

Fig. 2 Pore structure and gas sorption properties of $\mathbf{Z n - a t z - o b a . ~ V i e w s ~ o f ~ ( a ) ~ t h e ~ p o r e ~ s t r u c t u r e ~ a n d ~ ( b ) ~ t h e ~ C o n n o l l y ~ s u r f a c e ~ o f ~} Z n$-atz-oba when viewed along the $a$ - and c-axis, respectively. $\mathrm{H}$-atoms are omitted for clarity. (c) PXRD patterns confirm the bulk phase purity of $\mathrm{Zn}$-atz-oba. (d) Adsorption enthalpy profiles $\left(Q_{s t}\right)$ for $Z n$-atz-oba. (e) Gas sorption isotherms of Zn-atz-oba at $298 \mathrm{~K}$. (f) Binary 1:1 (v/v) IAST selectivity of Zn-atz-oba at $298 \mathrm{~K}$. color codes for (a) and (b): carbon = gray; nitrogen = blue; oxygen = red; Zn polyhedra in $(\mathbf{a})=$ tyrian purple; Connolly surface in $(\mathbf{b})=$ purple. 
(a)

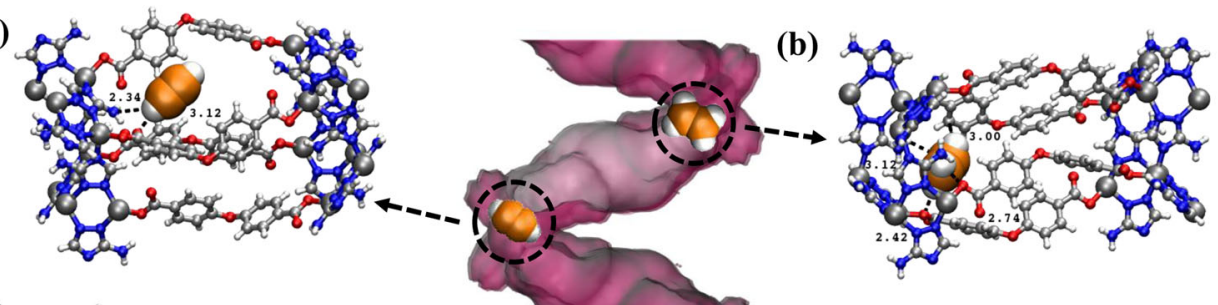

(c)

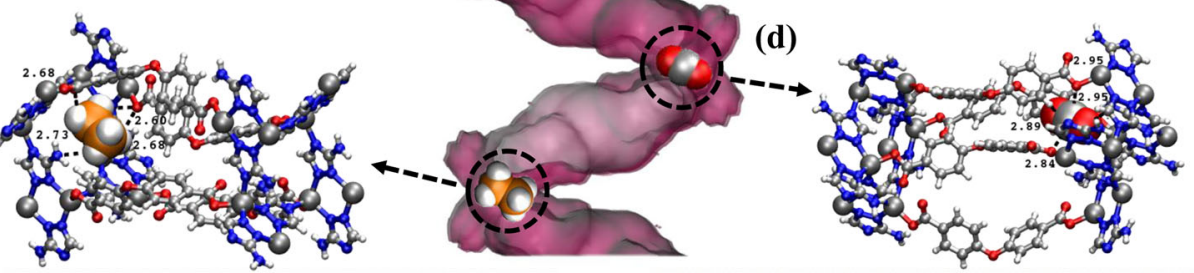

(e)

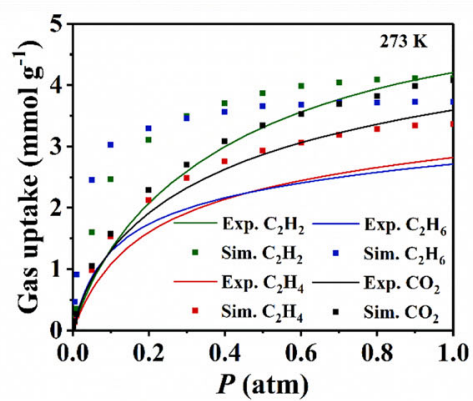

(f)

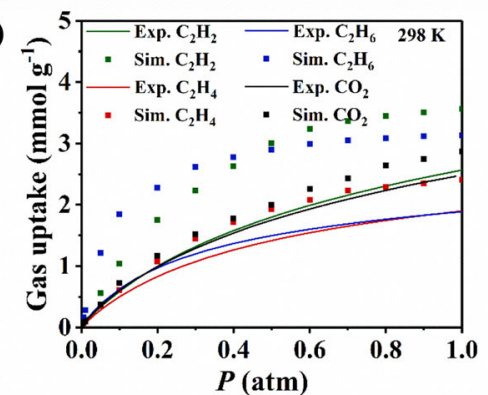

Fig. 3 Molecular modeling guided determination of primary adsorption sites and adsorption isotherms in Zn-atz-oba. The primary adsorption sites of (a) $\mathrm{C}_{2} \mathrm{H}_{2}$, (b) $\mathrm{C}_{2} \mathrm{H}_{4}$, (c) $\mathrm{C}_{2} \mathrm{H}_{6}$, and (d) $\mathrm{CO}_{2}$ in $\mathrm{Zn}$-atz-oba. Adsorbed gas molecules are presented in space-filling mode. color codes: $\mathrm{C}$ ( $\mathrm{Zn}$-atz-oba and $\mathrm{CO}_{2}$ ): gray; $\mathrm{C}$ ( $\mathrm{C} 2$ gases): orange; $\mathrm{H}$ : white; $\mathrm{O}$ : red; $\mathrm{N}$ : blue; $\mathrm{Zn}$ : silver. Experimental (solid lines with circles) and simulated (squares) adsorption isotherms for $\mathrm{C}_{2} \mathrm{H}_{2}$ (green), $\mathrm{C}_{2} \mathrm{H}_{4}$ (red), $\mathrm{C}_{2} \mathrm{H}_{6}$ (blue), and $\mathrm{CO}_{2}$ (black) at (e) $273 \mathrm{~K}$ and (f) $298 \mathrm{~K}$ and pressures up to 1 atm in $\mathrm{Zn}$-atz-oba.

pressure $(\leq 0.2 \mathrm{~atm})$, but are slightly higher than experimental values at higher pressures (Fig. 3). Moreover, it can be observed that the simulated uptakes for $\mathrm{C}_{2} \mathrm{H}_{2}$ and $\mathrm{C}_{2} \mathrm{H}_{6}$ significantly overestimate their corresponding experimental values for most of the state points considered. Since polarization contributes to less than $10 \%$ of the total energy for simulations of all four gases in Zn-atz-oba (see Supplementary Fig. 21), the overestimation of the theoretical uptakes compared with experiment might be attributable to the partial charges (Supplementary Data 1) and/or the repulsion/dispersion parameters (Supplementary Data 2) that were used for the MOF atoms (for crystallographic distances between MOF atoms see Supplementary Data 3; further details of the modeling study are provided in Supplementary Note 3: Modeling Study). Future work could exploit multiple MOF force field parameters for the simulations and investigate their effect upon the reliability of gas uptakes in this material. Although the simulated uptakes in $\mathrm{Zn}$-atz-oba are inconsistent with experimental data, the simulations still properly predicted that this material exhibits the lowest uptake for $\mathrm{C}_{2} \mathrm{H}_{4}$ within the considered pressure range at 273 and $298 \mathrm{~K}$. In addition, according to the simulations, $\mathrm{Zn}$-atz-oba was expected to display higher uptake for $\mathrm{C}_{2} \mathrm{H}_{6}$ within the low-pressure region $(<0.1 \mathrm{~atm})$ compared to the other three gases. This is also consistent with the finding that this MOF exhibited the highest initial $Q_{\text {st }}$ value toward $\mathrm{C}_{2} \mathrm{H}_{6}$ according to both experiment and simulation (Fig. 2d and Supplementary Table 4).

Molecular simulations revealed that the most favorable binding site for all adsorbates lies within the confined region enclosed by four atz linkers and three oba linkers (Fig. 3). In this region, $\mathrm{C}_{2} \mathrm{H}_{2}$ interacts with the $-\mathrm{NH}_{2}$ group of atz with $\mathrm{N} \cdots \mathrm{H}-\mathrm{C}$ distances of $2.34 \AA$ (Fig. 3a). $\mathrm{C}_{2} \mathrm{H}_{4}, \mathrm{C}_{2} \mathrm{H}_{6}$, and $\mathrm{CO}_{2}$ exhibit different orientations than $\mathrm{C}_{2} \mathrm{H}_{2}$, which allow them to make multiple contacts with the surrounding atoms of the framework. Most sorbent-sorbate interaction distances are longer for $\mathrm{C}_{2} \mathrm{H}_{4}$ versus $\mathrm{C}_{2} \mathrm{H}_{6}$ and $\mathrm{CO}_{2}$, indicating weaker interactions between $\mathrm{C}_{2} \mathrm{H}_{4}$ and the pores of Zn-atz-oba (Fig. 3b-d). The GCMC-calculated initial $Q_{\text {st }}$ values were determined and exhibit the following trend: $\mathrm{C}_{2} \mathrm{H}_{6}>\mathrm{CO}_{2}>\mathrm{C}_{2} \mathrm{H}_{2}>\mathrm{C}_{2} \mathrm{H}_{4}$ (see Supplementary Table 4). The greater $Q_{\text {st }}$ value for $\mathrm{C}_{2} \mathrm{H}_{6}$ versus $\mathrm{CO}_{2}$ in $\mathrm{Zn}$-atz-oba is supported by shorter interactions between $\mathrm{C}_{2} \mathrm{H}_{6}$ and $\mathrm{Zn}$-atz-oba, perhaps because of the larger molecular dimensions of $\mathrm{C}_{2} \mathrm{H}_{6}$ and repulsive interactions between the negatively charged $\mathrm{O}$ atoms of $\mathrm{CO}_{2}$ and the surrounding electronegative $\mathrm{N}$ atoms of the atz linkers at the binding site. Further, the close $\mathrm{N} \cdots \mathrm{H}-\mathrm{C}$ interactions exhibited by $\mathrm{C}_{2} \mathrm{H}_{2}$ are shorter than those of $\mathrm{C}_{2} \mathrm{H}_{4}$. Overall, the modeling studies support the experimental finding that $\mathrm{C}_{2} \mathrm{H}_{4}$ forms weaker interactions with $\mathrm{Zn}$-atz-oba than the other three gases.

Breakthrough experiments of $\mathbf{Z n - a t z - o b a . ~ T h e ~ g a s ~ s e p a r a t i o n ~}$ performance was determined by dynamic column breakthrough experiments performed with $\mathrm{Zn}$-atz-oba. In a typical breakthrough test at $298 \mathrm{~K}$ and ambient pressure, $\mathrm{C}_{2} \mathrm{H}_{4} / \mathrm{C}_{2} \mathrm{H}_{6}, \mathrm{C}_{2} \mathrm{H}_{2} /$ $\mathrm{C}_{2} \mathrm{H}_{4} / \mathrm{C}_{2} \mathrm{H}_{6}$, and $\mathrm{C}_{2} \mathrm{H}_{2} / \mathrm{C}_{2} \mathrm{H}_{4} / \mathrm{C}_{2} \mathrm{H}_{6} / \mathrm{CO}_{2}$ mixtures (equimolar mixtures, total gas pressure $=100 \mathrm{kPa}$ ) were passed through a packed column and the effluent streams were monitored by gas chromatography. In accordance with the pure gas sorption results and the molecular simulations derived understanding of the binding sites, the $\mathrm{Zn}$-atz-oba fixed-bed column eluted $\mathrm{C}_{2} \mathrm{H}_{4}$ with ultra-high purity in a single step from all three gas mixtures. As shown in Fig. $4 \mathrm{a}-\mathrm{c}, \mathrm{C}_{2} \mathrm{H}_{4}$ breaks through first at ca. 236, 177, and 130 min, respectively, and the impurities $\left(\mathrm{C}_{2} \mathrm{H}_{6}, \mathrm{C}_{2} \mathrm{H}_{2}\right.$, and $\left.\mathrm{CO}_{2}\right)$ break through 14,12 , and $10 \mathrm{~min}$ later, respectively. Before breakthrough of $\mathrm{C}_{2} \mathrm{H}_{6}, \mathrm{C}_{2} \mathrm{H}_{4}$ of polymer grade purity (>99.95\%) was collected at the outlet, revealing that $\mathrm{Zn}$-atz-oba achieved 
(a) Binary mixture
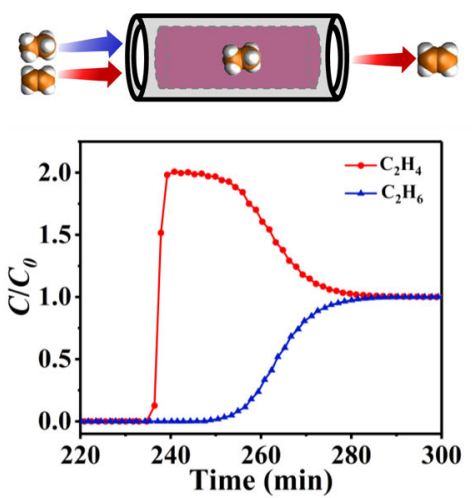

(d)

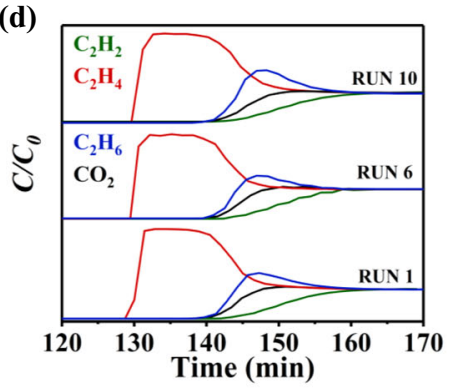

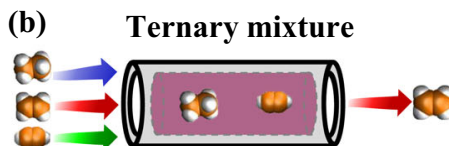
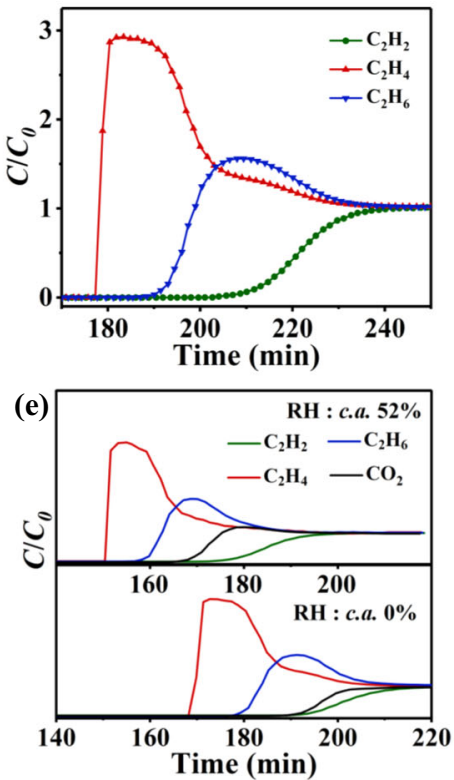
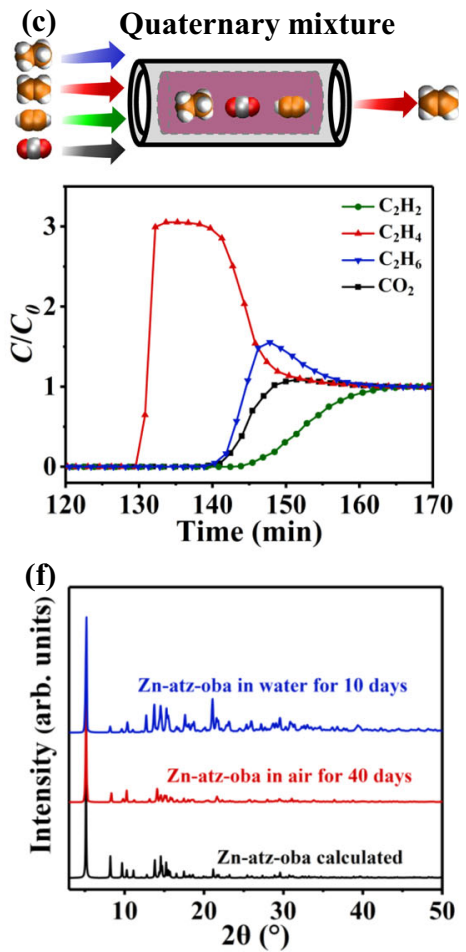

Fig. 4 Dynamic breakthrough experiments and stability tests. (a)-(c) Experimental breakthrough curves at $298 \mathrm{~K}$ for $\mathrm{C}_{2} \mathrm{H}_{4} / \mathrm{C}_{2} \mathrm{H}_{6}(1: 1)\left(\right.$ a), $\mathrm{C}_{2} \mathrm{H}_{2} / \mathrm{C}_{2} \mathrm{H}_{4} /$ $\mathrm{C}_{2} \mathrm{H}_{6}$ (1:1:1) (b), and $\mathrm{C}_{2} \mathrm{H}_{2} / \mathrm{C}_{2} \mathrm{H}_{4} / \mathrm{C}_{2} \mathrm{H}_{6} / \mathrm{CO}_{2}$ (1:1:1:1) (c) separations (equimolar mixtures; total gas pressure $100 \mathrm{kPa}$; total gas flow 1.4, 2.1 and $2.8 \mathrm{~cm}^{3}$ min -1 , respectively) based on $\mathrm{Zn}$-atz-oba $\left(6.3 \mathrm{~g}\right.$ ) packed column (C: Outlet gas concentration, $\mathrm{C}_{0}$ : Inlet gas concentration). (d) Dynamic breakthrough data obtained with $\mathrm{Zn}$-atz-oba fixed-bed in $1^{\text {st }}, 5^{\text {th }}$, and $10^{\text {th }}$ cycle when subjected to four-component $\mathrm{C}_{2} \mathrm{H}_{2} / \mathrm{C}_{2} \mathrm{H}_{4} / \mathrm{C}_{2} \mathrm{H}_{6} / \mathrm{CO}_{2}$ (1:1:1:1) mixture. e Fourcomponent (1:1:1:1) breakthrough experiment in the presence of water vapor at $288 \mathrm{~K}$ and $100 \mathrm{kPa}$ based on $\mathrm{Zn}$-atz-oba (7.0 g) packed column (total gas flow of $2.8 \mathrm{~cm}^{3} \mathrm{~min}^{-1}$ ). (f) PXRD patterns of $\mathrm{Zn}$-atz-oba after being subjected to air exposure and water immersion stability test conditions.

one-step purification of $\mathrm{C}_{2} \mathrm{H}_{4}$ by the coadsorption of $\mathrm{C}_{2} \mathrm{H}_{2}, \mathrm{C}_{2} \mathrm{H}_{6}$, and $\mathrm{CO}_{2}$ from $\mathrm{C}_{2} \mathrm{H}_{2} / \mathrm{C}_{2} \mathrm{H}_{4} / \mathrm{C}_{2} \mathrm{H}_{6} / \mathrm{CO}_{2}\left(>99.95 \% \mathrm{C}_{2} \mathrm{H}_{4}\right.$ productivity, $0.106 \mathrm{mmol} \mathrm{g}^{-1}$ ). To explore the recycling performance of $\mathrm{Zn}$-atz-oba, ten cycles of four-component breakthrough experiments were conducted. There was no loss of $\mathrm{C}_{2} \mathrm{H}_{4}$ retention time (Fig. $4 \mathrm{~d}$ ). In industrial $\mathrm{C} 2$ hydrocarbon gas streams, $\mathrm{C}_{2} \mathrm{H}_{2}$ only constitutes $\sim 1 \%$ of the total flow ${ }^{50}$. We also tested a $\mathrm{C}_{2} \mathrm{H}_{2} /$ $\mathrm{C}_{2} \mathrm{H}_{4} / \mathrm{C}_{2} \mathrm{H}_{6} / \mathrm{CO}_{2}(1 / 33 / 33 / 33)$ mixture under dynamic breakthrough using $7.4 \mathrm{~g} \mathrm{Zn}$-atz-oba packed in a fixed-bed. As shown in Fig. S25, polymer-grade ethylene was harvested from 1/33/33/33 gas mixture, followed by $\mathrm{C}_{2} \mathrm{H}_{6}, \mathrm{CO}_{2}$, and $\mathrm{C}_{2} \mathrm{H}_{2}$. As a typical contaminant in downstream feedstocks, water vapor is present in the industrially produced $\mathrm{C}_{2}-\mathrm{CO}_{2}$ stream ${ }^{51}$, so breakthrough experiments in the presence of water vapor were conducted. As revealed by Fig. 4e, fractional pressure reduction of $\mathrm{C}_{2} \mathrm{H}_{2}, \mathrm{C}_{2} \mathrm{H}_{4}$, $\mathrm{C}_{2} \mathrm{H}_{6}$, and $\mathrm{CO}_{2}$ in the presence of water vapor reduced the adsorption capacity of $\mathrm{Zn}$-atz-oba. This is reflected in a reduced $\mathrm{C}_{2} \mathrm{H}_{4}$ breakthrough time, from c.a. $170 \mathrm{~min}$ to c.a. $150 \mathrm{~min}$. 4-component $\mathrm{C}_{2} \mathrm{H}_{2} / \mathrm{C}_{2} \mathrm{H}_{4} / \mathrm{C}_{2} \mathrm{H}_{6} / \mathrm{CO}_{2} \quad$ (1:1:1:1) breakthrough experiments in the presence of water vapor (relative humidity $52 \%$ ) also resulted in a reduced retention time but a consistent gas outflow sequence. Nevertheless, $\mathrm{C}_{2} \mathrm{H}_{4}$ with effluent purity $>99.95 \%$ was collected at the column outlet. We attribute the shorter retention time under $52 \%$ humidity to the presence of water vapor in the breakthrough pipeline and competing sorption of water with the other four gases. After ambient air exposure for 30 days or water immersion for 10 days, PXRD patterns (Fig. 4f) and $\mathrm{N}_{2}$ isotherms at $77 \mathrm{~K}$ (including pore distribution, Supplementary Figs. 26 and 27) of regenerated Zn-atz-oba indicated that it is stable to both humid air and liquid water. Temperature- programmed desorption of the fully adsorbed column was conducted after achieving full saturation and revealed that the $\mathrm{Zn}$-atzoba bed could be regenerated within $50 \mathrm{~min}$ at $333 \mathrm{~K}$ under $\mathrm{He}$ flow $\left(30 \mathrm{~cm}^{3} \mathrm{~min}^{-1}\right)$. Even under ambient conditions $(298 \mathrm{~K}$ and $100 \mathrm{kPa}$ ), regeneration was achieved within $140 \mathrm{~min}$ under $\mathrm{He}$ flow of $20 \mathrm{~cm}^{3} \mathrm{~min}^{-1}$ (Supplementary Fig. 23), confirming that there is indeed a relatively low energy footprint for $\mathrm{Zn}$-atz-oba regeneration.

\section{Discussion}

If one compares the performances of previously reported physisorbents in the context of ethylene purification from binary mixtures ${ }^{15-20,22-30,32,46}\left(\mathrm{C}_{2} \mathrm{H}_{2} / \mathrm{C}_{2} \mathrm{H}_{4}, \mathrm{C}_{2} \mathrm{H}_{6} / \mathrm{C}_{2} \mathrm{H}_{4}\right.$, and $\left.\mathrm{C}_{2} \mathrm{H}_{4} / \mathrm{CO}_{2}\right)$ and ternary mixtures ${ }^{35,36,39-41}\left(\mathrm{C}_{2} \mathrm{H}_{2} / \mathrm{C}_{2} \mathrm{H}_{4} / \mathrm{C}_{2} \mathrm{H}_{6}, \mathrm{C}_{2} \mathrm{H}_{2} / \mathrm{C}_{2} \mathrm{H}_{4} / \mathrm{CO}_{2}\right.$, and $\mathrm{C}_{2} \mathrm{H}_{6} / \mathrm{C}_{2} \mathrm{H}_{4} / \mathrm{CO}_{2}$ ), it is evident that $\mathrm{Zn}$-atz-oba represents a benchmark in terms of its performance parameters (Fig. 5). Specifically, $\mathrm{Zn}$-atz-oba coadsorbs three gases, $\mathrm{C}_{2} \mathrm{H}_{2}, \mathrm{C}_{2} \mathrm{H}_{6}$, and $\mathrm{CO}_{2}$, to produce polymer-grade ( $>99.95 \%) \mathrm{C}_{2} \mathrm{H}_{4}$ in just one step. We attribute this performance to the unusual pore environment in $\mathrm{Zn}$-atzoba, which enables roughly equal affinity towards $\mathrm{C}_{2} \mathrm{H}_{2}, \mathrm{C}_{2} \mathrm{H}_{6}$, and $\mathrm{CO}_{2}$ over $\mathrm{C}_{2} \mathrm{H}_{4}$. Future studies will focus upon crystal engineering of second-generation variants to further improve the purification performances of other gas mixtures of industrial relevance.

\section{Methods}

General. All reagents were obtained from vendors and used as received without further purification. Powder X-ray diffraction (PXRD) data were collected with a Rigaku-Miniflex-600 diffractometer at a scanning rate of $5^{\circ} \mathrm{min}^{-1}$ using $\mathrm{Cu} \mathrm{K}_{\alpha}$ radiation. Thermogravimetric analysis (TGA) data were obtained using Mettler TG DSC 3+ Thermogravimetric Analyzer. In TGA measurements, the sample was 


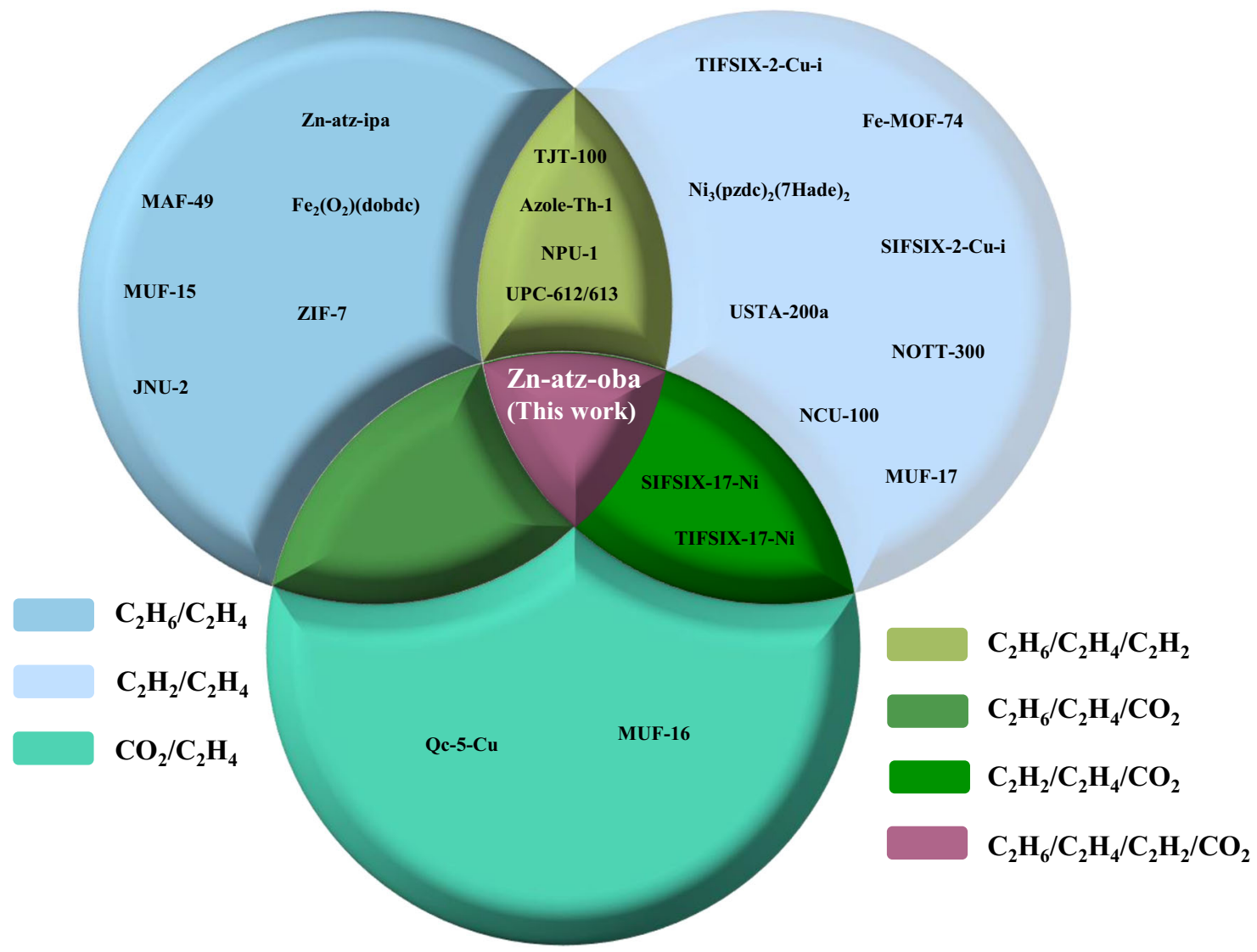

Fig. 5 Physisorbents studied for $\mathbf{C}_{\mathbf{2}} \mathbf{H}_{\mathbf{4}}$ purification. Comparison of physisorbents that can purify $\mathrm{C}_{2} \mathrm{H}_{4}$ from binary (sky blue) $15-20,22-30,32,46$, ternary (olive green) ${ }^{35,36,39-41}$ and quaternary mixtures (lilac, this work) under ambient conditions.

heated from $298 \mathrm{~K}$ to $1073 \mathrm{~K}$ under Ar atmosphere at a heating rate of $10 \mathrm{~K} \mathrm{~min}^{-1}$. The morphology was examined using scanning electron microscopy (FESEM, Verios G4, FEI).

Synthesis of Zn-atz-oba. A mixture of $\mathrm{Zn}\left(\mathrm{NO}_{3}\right)_{2} \cdot 6 \mathrm{H}_{2} \mathrm{O}(10 \mathrm{mmol}, 2.98 \mathrm{~g}), \mathrm{H}_{2} \mathrm{oba}$ ( $5 \mathrm{mmol}, 1.29 \mathrm{~g}$ ), Hatz (10 mmol, $0.84 \mathrm{~g})$, DMF (40 mL), $\mathrm{MeOH}(40 \mathrm{~mL})$, and $\mathrm{H}_{2} \mathrm{O}$ $(20 \mathrm{~mL})$ was sealed in a $250 \mathrm{ml}$ borosilicate bottle and sonicated for five minutes. The reaction mixture was then solvothermally treated at $403 \mathrm{~K}$ for 3 days before naturally cooling it to room temperature. The as-synthesized sample $\mathrm{Zn}$-atz-oba was washed with fresh $\mathrm{DMF}, \mathrm{MeOH}$, and $\mathrm{H}_{2} \mathrm{O}$, and exchanged with $\mathrm{MeOH}$ three times daily for three days and then activated at $353 \mathrm{~K}$ in vacuum for $12 \mathrm{~h}$.

Single-component gas sorption experiments. A Micromeritics 3Flex was used for recording all gas sorption isotherms, $\mathrm{N}_{2}(77 \mathrm{~K}), \mathrm{C}_{2} \mathrm{H}_{2}, \mathrm{C}_{2} \mathrm{H}_{4}, \mathrm{C}_{2} \mathrm{H}_{6}$, and $\mathrm{CO}_{2}$ (each, 273 and $298 \mathrm{~K}$ ). For $\mathrm{N}_{2}$ adsorption isotherms, the temperature was controlled at $77 \mathrm{~K}$ using a Dewar containing $4 \mathrm{~L}$ liquid $\mathrm{N}_{2}$. Precise control of 273 and $298 \mathrm{~K}$ temperatures was implemented by a dc-2006 from Ningbo Scientz Biotechnology, which contained a cyclic control system of ethylene glycol and water mixture $(\mathrm{v} / \mathrm{v}=1: 1)$. Zn-atz-oba was degassed at $298 \mathrm{~K}$ under high vacuum for $4 \mathrm{~h}$ to regenerate in between consecutive isotherm measurements.

Dynamic gas breakthrough experiments. Breakthrough curves were recorded by an in-house custom-built rig (Supplementary Fig. 22). Equimolar $\mathrm{C}_{2} \mathrm{H}_{6} / \mathrm{C}_{2} \mathrm{H}_{4}(1: 1)$, $\mathrm{C}_{2} \mathrm{H}_{2} / \mathrm{C}_{2} \mathrm{H}_{4} / \mathrm{C}_{2} \mathrm{H}_{6}$ (1:1:1) and $\mathrm{C}_{2} \mathrm{H}_{2} / \mathrm{C}_{2} \mathrm{H}_{4} / \mathrm{C}_{2} \mathrm{H}_{6} / \mathrm{CO}_{2}$ (1:1:1:1) gas mixtures (total gas pressure and flow: $100 \mathrm{kPa}$ and $1.4,2.1$, and $2.8 \mathrm{~cm}^{3} \mathrm{~min}^{-1}$, respectively) were subjected through the $\mathrm{Zn}$-atz-oba packed column $(6.3 \mathrm{~g})$ at $298 \mathrm{~K}$, and the outlet gas concentrations and composition were monitored by a gas chromatography analyzer (Carrier gas: He, TCD-Thermal Conductivity Detector, detection limit 0.1 $\mathrm{ppm})$. During gas breakthrough cycling tests, $\mathrm{Zn}$-atz-oba packed in the column was regenerated under He flow of $30 \mathrm{~cm}^{3} \mathrm{~min}^{-1}$ at $333 \mathrm{~K}$ for $2 \mathrm{~h}$, after each breakthrough experiment.

\section{Data availability}

The sorption data; molecular simulations and breakthrough data generated in this study are provided in the Supplementary Information/Source Data file ${ }^{52}$.

\section{Code availability}

The codes used to analyse all the data generated in this study are provided in the Supplementary Information (Supplementary Note 1: Calculations, Supplementary Note 2: Adsorption enthalpy calculation and Supplementary Note 3: Modeling Study) and/or the Source Data file $\mathrm{e}^{52}$.

Received: 19 April 2021; Accepted: 6 October 2021; Published online: 11 November 2021

\section{References}

1. Ethylene (ET): 2019 World Market Outlook and Forecast up to 2023. https:// www.researchandmarkets.com/ (retrieved Jan 2019).

2. Sholl, D. S. \& Lively, R. P. Seven chemical separations to change the world. Nature 532, 435-437 (2016).

3. Sadrameli, S. M. Thermal/catalytic cracking of hydrocarbons for the production of olefins: a state-of-the-art review I: thermal cracking review. Fuel 140, 102-115 (2015).

4. Safarik, D. J. \& Eldridge, R. B. Olefin/paraffin separations by reactive absorption: a review. Ind. Eng. Chem. Res. 37, 2571-2581 (1998).

5. Ren, T., Patel, M. \& Blok, K. Olefins from conventional and heavy feedstocks: energy use in steam cracking and alternative processes. Energy 31, 425-451 (2006).

6. P. A. Angelini, T et al. Materials for Separation Technologies: Energy and Emission Reduction Opportunities. Oak Ridge, TN (United States): Oak Ridge National Lab. (ORNL); 2005.

7. Wang, H., Liu, Y. \& Li, J. Hydrocarbon separation: designer metal-organic frameworks for size-exclusion-based hydrocarbon separations: progress and challenges. Adv. Mater. 32, 2002603 (2020).

8. Li, J., Kuppler, R. J. \& Zhou, H. Selective gas adsorption and separation in metal-organic frameworks. Chem. Soc. Rev. 38, 1477-1504 (2009). 
9. Perry, J. J., Perman, J. A. \& Zaworotko, M. J. Design and synthesis of metalorganic frameworks using metal-organic polyhedra as supermolecular building blocks. Chem. Soc. Rev. 38, 1400-1417 (2009).

10. MacGillivray L.-R. Metal-Organic Frameworks: Design and Application (ed. MacGillivray, L.-R.) (Wiley, Hoboken, NJ, 2010).

11. Furukawa, H., Cordova, K. E., O'Keeffe, M. \& Yaghi, O. M. The chemistry and applications of metal-organic frameworks. Science 341, 1230444 (2013).

12. Kitagawa, S., Kitaura, R. \& Noro, S. Functional porous coordination polymers. Angew. Chem. Int. Ed. 43, 2334-2375 (2004).

13. Mukherjee, S., Sensharma, D., Chen, K. \& Zaworotko, M. J. Crystal engineering of porous coordination networks to enable separation of $\mathrm{C} 2$ hydrocarbons. Chem. Commun. 56, 10419-10441 (2020).

14. Yang, H. et al. Pore-Space-Partition-Enabled exceptional ethane uptake and ethane-selective ethane-ethylene separation. J. Am. Chem. Soc. 142, 2222-2227 (2020).

15. Liao, P., Zhang, W., Zhang, J. \& Chen, X. Efficient purification of ethene by an ethane-trapping metal-organic framework. Nat. Commun. 6, 8697 (2015).

16. Qazvini, O. T., Babarao, R., Shi, Z., Zhang, Y. \& Telfer, S. G. A robust ethanetrapping metal-organic framework with a high capacity for ethylene purification. J. Am. Chem. Soc. 141, 5014-5020 (2019).

17. Sun, F. et al. Microporous metal-organic framework with a completely reversed adsorption relationship for $\mathrm{C} 2$ hydrocarbons at room temperature. ACS Appl. Mater. Interfaces 12, 6105-6111 (2020).

18. Li, L. et al. Ethane/ethylene separation in a metal-organic framework with iron-peroxo sites. Science 362, 443-446 (2018).

19. Zeng, H. et al. Cage-Interconnected metal-organic framework with tailored apertures for efficient $\mathrm{C}_{2} \mathrm{H}_{6} / \mathrm{C}_{2} \mathrm{H}_{4}$ separation under humid conditions. J. Am. Chem. Soc. 141, 20390-20396 (2019).

20. Gücüyener, C., van den Bergh, J., Gascon, J. \& Kapteijn, F. Ethane/Ethene separation turned on its head: Selective ethane adsorption on the metalorganic framework ZIF-7 through a gate-opening mechanism. J. Am. Chem. Soc. 132, 17704-17706 (2010).

21. Lysova, A. A. et al. A series of mesoporous metal-organic frameworks with tunable windows sizes and exceptionally high ethane over ethylene adsorption selectivity. Angew. Chem. Int. Ed. 59, 20561-20567 (2020).

22. Bloch, E. D. et al. Hydrocarbon separations in a metal-organic framework with open iron (II) coordination sites. Science 335, 1606-1610 (2012).

23. Zhang, Z. et al. Efficient trapping of trace acetylene from ethylene in an ultramicroporous metal-organic framework: synergistic effect of high-density open metal and electronegative sites. Angew. Chem. Int. Ed. 59, 18927-18932 (2020).

24. Cui, X. et al. Pore chemistry and size control in hybrid porous materials for acetylene capture from ethylene. Science 353, 141-144 (2016).

25. Li, B. et al. An ideal molecular sieve for acetylene removal from ethylene with record selectivity and productivity. Adv. Mater. 29, 1704210 (2017)

26. Chen, $\mathrm{K}$. et al. Benchmark $\mathrm{C}_{2} \mathrm{H}_{2} / \mathrm{CO}_{2}$ and $\mathrm{CO}_{2} / \mathrm{C}_{2} \mathrm{H}_{2}$ separation by two closely related hybrid ultramicroporous materials. Chem 1, 753-765 (2016).

27. Yang, S. et al. Supramolecular binding and separation of hydrocarbons within a functionalized porous metal-organic framework. Nat. Chem. 7, 121-129 (2015).

28. Wang, J. et al. Optimizing pore space for flexible-robust metal-organic framework to boost trace acetylene removal. J. Am. Chem. Soc. 142, 9744-9751 (2020).

29. Qazvini, O. T., Babarao, R. \& Telfer, S. G. Multipurpose metal-organic framework for the adsorption of acetylene: ethylene purification and carbon dioxide removal. Chem. Mater. 31, 4919-4926 (2019).

30. He, T., Xiao, Y., Zhao, Q., Zhou, M. \& He, G. Ultramicroporous metal-organic framework Qc-5-Cu for highly selective adsorption of $\mathrm{CO}_{2}$ from $\mathrm{C}_{2} \mathrm{H}_{4}$ stream. Ind. Eng. Chem. Res. 59, 3153-3161 (2020).

31. Horike, S. et al. Dense coordination network capable of selective $\mathrm{CO}_{2}$ capture from C1 and C2 hydrocarbons. J. Am. Chem. Soc. 134, 9852-9855 (2012).

32. Qazvini, O. T., Babarao, R. \& Telfer, S. G. Selective capture of carbon dioxide from hydrocarbons using a metal-organic framework. Nat. Commun. 12, 197 (2021).

33. Mukherjee, S. \& Zaworotko, M. J. Crystal engineering of hybrid coordination networks: from form to function. Trends Chem. 2, 506-518 (2020).

34. Liu, S. et al. Efficient separation of acetylene and carbon dioxide in a decorated zeolite. Angew. Chem. Int. Ed. 60, 6526-6532 (2021).

35. Hao, H. G. et al. Simultaneous trapping of $\mathrm{C}_{2} \mathrm{H}_{2}$ and $\mathrm{C}_{2} \mathrm{H}_{6}$ from a ternary mixture of $\mathrm{C}_{2} \mathrm{H}_{2} / \mathrm{C}_{2} \mathrm{H}_{4} / \mathrm{C}_{2} \mathrm{H}_{6}$ in a robust metal-organic framework for the purification of $\mathrm{C}_{2} \mathrm{H}_{4}$. Angew. Chem. Int. Ed. 57, 16067-16071 (2018).

36. $\mathrm{Xu}, \mathrm{Z}$. et al. A robust Th-azole framework for highly efficient purification of $\mathrm{C}_{2} \mathrm{H}_{4}$ from a $\mathrm{C}_{2} \mathrm{H}_{4} / \mathrm{C}_{2} \mathrm{H}_{2} / \mathrm{C}_{2} \mathrm{H}_{6}$ mixture. Nat. Commun. 11, 3163 (2020).

37. Dong, Q. et al. Tuning gate-opening of a flexible metal-organic framework for ternary gas sieving separation. Angew. Chem. Int. Ed. 59, 22756-22762 (2020).

38. Yang, S. et al. Efficient purification of ethylene from $\mathrm{C} 2$ hydrocarbons with an $\mathrm{C}_{2} \mathrm{H}_{6} / \mathrm{C}_{2} \mathrm{H}_{2}$-selective metal-organic framework. ACS Appl. Mater. Interfaces 13, 962-969 (2021).
39. Zhu, B. et al. Pore engineering for one-step ethylene purification from a threecomponent hydrocarbon mixture. J. Am. Chem. Soc. 143, 1485-1492 (2021).

40. Mukherjee, S. et al. Amino-Functionalised hybrid ultramicroporous materials that enable single-step ethylene purification from a ternary mixture. Angew. Chem. Int. Ed. 60, 10902-10909 (2021)

41. Wang, Y. et al. One-step ethylene purification from an acetylene/ethylene/ ethane ternary mixture by cyclopentadiene cobalt-functionalized metalorganic frameworks. Angew. Chem. Int. Ed. 60, 11350-11358 (2021).

42. O' Hearn, D. J., Bajpai, A. \& Zaworotko, M. J. The "Chemistree" of porous coordination networks: taxonomic classification of porous solids to guide crystal engineering studies. Small 2006351 (2021).

43. Nugent, P. et al. Porous materials with optimal adsorption thermodynamics and kinetics for $\mathrm{CO}_{2}$ separation. Nature 495, 80-84 (2013).

44. Lin, R. et al. Molecular sieving of ethylene from ethane using a rigid metalorganic framework. Nat. Mater. 17, 1128-1133 (2018).

45. Liao, P., Huang, N., Zhang, W., Zhang, J. \& Chen, X. Controlling guest conformation for efficient purification of butadiene. Science 356, 1193-1196 (2017).

46. Chen, K. et al. Synergistic sorbent separation for one-step ethylene purification from a four-component mixture. Science 366, 241-246 (2019).

47. Chen, K. et al. New Zn-aminotriazolate-dicarboxylate frameworks: synthesis, structures, and adsorption properties. Cryst. Growth Des. 13, 2118-2123 (2013).

48. Spek, A. L. Structure validation in chemical crystallography. Acta Cryst. D65, 148-155 (2009).

49. Myers, A. L. \& Prausnitz, J. M. Thermodynamics of mixed-gas adsorption. AIChE J. 11, 121-127 (1965).

50. Bao, Z. et al. Potential of microporous metal-organic frameworks for separation of hydrocarbon mixtures. Energy Environ. Sci. 9, 3612-3641 (2016).

51. Yancheshmeh, M. S. S. et al. Modeling of ethane pyrolysis process: a study on effects of steam and carbon dioxide on ethylene and hydrogen productions. Chem. Eng. J. 215-216, 550-560 (2013).

52. Jian-Wei, C. (2021): Zn-atz-oba gas sorption data (Exp. and Sim.) is provided as a Figshare dataset: https://doi.org/10.6084/m9.figshare.16571151.v1.

\section{Acknowledgements}

K.J.C. acknowledges the National Natural Science Foundation of China (grant number 22071195, 21805227) and Fundamental Research Funds for the Central Universities (grant number 3102017jc01001). T.W. acknowledges the National Natural Science Foundation of China (grant number 21905229). M.J.Z. acknowledges the Science Foundation Ireland (awards 13/RP/B2549, 16/IA/4624) and the European Research Council (award ADG 885695). S.M. acknowledges the Alexander von Humboldt Foundation for the award of a postdoctoral research fellowship. We would like to thank the Analytical \& Testing Center of Northwestern Polytechnical University and eceshi (www.eceshi.com) for SEM and TGA testing, respectively. T.P., K.A.F., and B.S. acknowledge the National Science Foundation (Award No. DMR-1607989), including support from the Major Research Instrumentation Program (Award No. CHE-1531590) Computational resources were made available by a XSEDE Grant (No. TG-DMR090028) and by Research Computing at the University of South Florida.

\section{Author contributions}

K.J.C. and M.J.Z. designed the project. J.W.C. and H.J.T synthesized the compounds. J.W.C. collected and analyzed all adsorption data. T.Z. and T.W. collected and analyzed the power X-ray diffraction. T.P., K.A.F., and B.S. performed the classical molecular simulations. J.W.C., S.M., and X.J. collected the experimental breakthrough data. S.M. and Y.W contributed to formal analysis and data curation. J.W.C., S.M., and K.J.C. wrote the paper, and all authors contributed to revise the manuscript.

\section{Competing interests}

The authors declare no competing interests.

\section{Additional information}

Supplementary information The online version contains supplementary material available at https://doi.org/10.1038/s41467-021-26473-8.

Correspondence and requests for materials should be addressed to Michael J. Zaworotko or Kai-Jie Chen.

Peer review information Nature Communications thanks the anonymous reviewer(s) for their contribution to the peer review of this work.

Reprints and permission information is available at http://www.nature.com/reprints

Publisher's note Springer Nature remains neutral with regard to jurisdictional claims in published maps and institutional affiliations. 
(c) (i) Open Access This article is licensed under a Creative Commons Attribution 4.0 International License, which permits use, sharing, adaptation, distribution and reproduction in any medium or format, as long as you give appropriate credit to the original author(s) and the source, provide a link to the Creative Commons license, and indicate if changes were made. The images or other third party material in this article are included in the article's Creative Commons license, unless indicated otherwise in a credit line to the material. If material is not included in the article's Creative Commons license and your intended use is not permitted by statutory regulation or exceeds the permitted use, you will need to obtain permission directly from the copyright holder. To view a copy of this license, visit http://creativecommons.org/ licenses/by/4.0/.

(C) The Author(s) 2021 